\title{
Manajemen Program Peminatan Peserta Didik Di SMA
}

\author{
Ceri Setiyati \\ SMAN 1 Bantul Yogyakarya \\ cerisetiyati@gmail.com \\ Siti Mariah \\ FKIP Universitas Sarjanawiyata Tamansiswa Yogyakarya \\ siti.mariah@ustjogja.ac.id
}

\begin{abstract}
The purpose of the study to describe the management of interest programs of learners in the Curriculum 2013 in SMA Negeri 2 Bantul Yogyakarta, including planning, organizing, implementation, and supervision. This type of research is qualitative with data collection techniques: observation, interview, and documentation. Informants are principals, vice principals, teachers, and students. Techniques to check the validity of the data used are observations and triangulation. Data analysis techniques for data reduction, data presentation, and conclusion. The result of the research indicates that the management of the program of the student's interest is well implemented, covering: planning of the program of interest of the learners is done through the formation of the committee, determining the kinds and quota, instrument and budget; organizing determines working mechanisms, division of tasks and creating a conducive environment; implementation is done through the determination of specialization program, learning process and self-development implementation; and supervision through the compilation of curriculum documents, PPDB reports and supervision of learning.
\end{abstract}

Keywords: Management, The Program of The Student's Interest

\section{Article Info}

\section{PENDAHULUAN}

Kurikulum 2013 untuk jenjang SMA mengubah istilah penjurusan menjadi peminatan peserta didik, yang sudah diwajibkan memilih program peminatan di kelas X semester satu. Berdasarkan survei tentang hambatan-hambatan dalam proses peminatan di SMA Negeri Se-Kota Surabaya yang dilakukan oleh Friska Yusmila Dewi dan Wiryo Nuryono (2014), menunjukkan bahwa hambatan yang terjadi dalam program peminatan adalah banyaknya orang tua yang memaksakan anaknya untuk masuk ke kelompok peminatan MIA, sedangkan anaknya tidak minat MIA. Untuk mengatasi hal tersebut Waka Kurikulum bekerjasama dengan Guru untuk melakukan wawancara dengan orang tua.

Berdasarkan hasil penelitian Rini Suwandi R dan Elisabeth Christiana (2013), menunjukkan bahwa sebesar $16 \%$ peserta didik yang pindah peminatan. Dalam pelaksanaan layanan peminatan hambatan yang ditemui seperti hasil penempatan yang tidak sesuai dengan dukungan orangtua. Belum semua sekolah di SMA melaksanakan kurikulum 2013. Untuk melaksanakan program peminatan 
peserta didik dalam Kurikulum 2013 perlu manajemen yang baik.

Permen Dikbud No 69 tahun 2013 tentang kerangka dasar dan struktur kurikulum SMA/MA diatur bahwa pemilihan kelompok peminatan didasarkan pada nilai raport SMP/MTs, nilai ujian Nasional SMP/MTs, rekomendasi guru bimbingan konseling di SMP, hasil tes penempatan ketika mendaftar di SMA, dan hasil test bakat minat oleh psikolog. Peminatan dimaksudkan untuk memenuhi kepentingan peserta didik dalam rangka perkembangan dan kesuksesan mereka secara optimal, sesuai dengan kemampuan dasar umum (kecerdasan), bakat, minat, dan kecenderungan pilihan masing-masing peserta didik, khususnya berkenaan dengan peminatan akademik, kejuruan, dan studi lanjutan.

Peminatan peserta didik merupakan upaya advokasi dan fasilitasi perkembangan peserta didik agar secara aktif mengembangkan potensi dirinya untuk memiliki kekuatan spiritual keagamaan, pengendalian diri, kepribadian, kecerdasan, akhlak mulia, serta keterampilan yang diperlukan dirinya, masyarakat, bangsa, dan negara (arahan Pasal 1 angka 1 UU Nomor 20 Tahun 2003 tentang Menentukan Pendidikan Nasional) sehingga mencapai perkembangan optimal.

Implementasi kurikulum 2013 akan dapat menimbulkan masalah bagi peserta didik SMA yang tidak mampu di dalam menentukan pilihan peminatan, baik kelompok mata pelajaran maupun mata pelajaran secara tepat, sehingga akan menimbulkan kesulitan dan kecenderungan gagal dalam belajar Untuk mencegah terjadinya masalah pada diri peserta didik maka diperlukan adanya usaha untuk membantu memandirikan peserta didik melalui pengambilan keputusan terkait dengan memilih, menentukan, meraih serta mempertahankan karier untuk mewujudkan kehidupan yang produktif dan sejahtera, serta untuk menjadi warga masyarakat yang peduli kemaslahatan umum melalui (upaya) pendidikan.

SMA Negeri 2 Bantul merupakan salah satu dari 19 sekolah negeri di Kabupaten Bantul yang sudah menerapkan Kurikulum 2013 sejak tahun ajaran 2013/2014. SMA Negeri 2 Bantul sudah mempunyai pengalaman dalam manajemen peminatan kurikulum 2013 dan menghasilkan peserta didik yang berprestasi sesuai dengan potensinya sehingga perlu dikaji bagaimana fungsi manajemen yang diterapkan. Tujuan penelitian adalah mendeskripsikan manajemen program peminatan peserta didik dalam Kurikulum 2013 TP 2016 / 2017 di SMA Negeri 2 Bantul yang meliputi: perencanaan, pengorganisasian, pelaksanaan, pengawasan dan faktor pendukung dan penghambat.

\section{METODE PENELITIAN}

Penelitian ini menggunakan metode kualitatif di SMA Negeri 2 Bantul dengan alasan sebagai berikut: piloting Kurikulum 2013, sekolah favorit dan menjadi ikon pendidikan di Kabupaten Bantul dan mempunyai prestasi akademik dan non akademik. Sumber data penelitian adalah: Informan (kepala sekolah, wakil kepala sekolah, guru dan siswa), tempat dan kegiatan sekolah, dokumen sekolah.

Teknik pengumpulan data penelitian ini berupa wawancara, observasi dan dokumentasi. Untuk mengumpulkan data penelitian dibuat kisi-kisi sumber data tentang manajemen penentuan peminatan peserta didik Kurikulum 2013 di SMA Negeri 2 Bantul. Kisi-kisi sumber data penelitian yang berisi fokus masalah dan aspek-aspek yang diteliti dan menentukan sumber data dan teknik pengumpulan. Peneliti ikut berpartisipasi selama di lapangan, mencatat secara hati-hati apa yang terjadi, melakukan analisis reflektif terhadap berbagai dokumen yang ditemukan di lapangan dan membuat laporan secara mendetail mengenai manajemen program peminatan peserta didik dalam Kurikulum 2013 di SMA Negeri 2 Bantul. 
Teknik analisis data menggunakan reduksi data, penyajian data dan penarikan kesimpulan. Untuk menguji keabsahan data dengan cara triangulasi, ketekunan penelitian dan perpanjangan pengamatan. Hasil wawancara, observasi dan dokumentasi yang sangat banyak kemudian direduksi dengan cara memilih data yang mendukung pada tujuan penelitian. Data yang sudah dipilih kemudian diringkas, difokuskan, digolongkan dan membuang data yang tidak diperlukan dan mengorganisasi data. Data yang sudah direduksi kemudian disajikan dalam bentuk uraian naratif, bagan, hubungan antar kategori serta diagram alur. Setelah itu dilakukan verifikasi data maka dapat ditarik kesimpulan berdasarkan hasil penelitian yang disajikan dalam bentuk narasi sesuai dengan tujuan dari penelitian tentang manajemen peminatan peserta didik Kurikulum 2013.

Data yang sudah dianalisis disajikan dalam hasil penelitian. Hal ini sesuai dengan dengan pendapat Sugiyono (2015:405), data yang diperoleh di lapangan jumlahnya cukup banyak untuk itu perlu dicatat secara teliti dan rinci. Mereduksi data berarti merangkum, memilih hal-hal yang pokok dari data dan memfokuskan pada hal-hal penting untuk dicari tema dan polanya sehingga akan memberi gambaran yang lebih jelas dan mempermudah peneliti untuk mengumpulkan data selanjutnya dan mencarinya bila diperlukan. Pada penelitian ini uji validitas yang digunakan peneliti adalah triangulasi. Triangulasi merupakan teknik pemeriksaan keabsahan data melalui sumber lain. Teknik ini bertujuan untuk mengecek kebenaran data yang diperoleh. Triangulasi ditempuh peneliti melalui beberapa cara, yaitu: sumber data, Metode dan mengkonsultasikan data dengan para ahli/dosen pembimbing). Menurut Sugiyono (2010: 117), Validitas merupakan derajat ketepatan antara data yang terjadi pada objek penelitian dengan data yang dapat dilaporkan oleh peneliti. Data dinyatakan valid apabila data yang dilaporkan 148 oleh peneliti tidak berbeda dengan data yang sesungguhnya terjadi pada objek penelitian.

\section{Hasil Penelitian}

SMA Negeri 2 Bantul sebagai piloting Kurikulum 2013, melaksanakan penentuan program peminatan peserta didik di kelas $\mathrm{X}$ semester gasal. Berdasarkan hasil penelitian diperoleh informasi bahwa program peminatan peserta didik dalam Kurikulum 2013 tahun pelajaran 2016/2017 di SMA Negeri 2 Bantul sebagai berikut:

\section{Perencanaan Program Peminatan}

Perencanaan program peminatan peserta didik Kurikulum 2013 di SMA Negeri 2 Bantul ditentukan sesuai dengan kuota dan jenis program, ketersediaan guru, sarana prasarana, serta jumlah jam setiap mata pelajaran yang sesuai dengan struktur kurikulum 2013 ,serta sarana dan prasarana yang ada. Sebagaiman dikemukakan infromasn bahwa: “... SMA Negeri 2 Bantul pada tahun pelajaran ini menentukan jumlah kelas peminatan X MIPA sebanyak 7 dan kelas peminatan XIPS sebanyak 2" (Ww.Ks.Is:27.09.16). Selanjutnya sekolah membetuk panitia penentuan program peminatan yang terintegrasi pada panitia PPDB..." (Ww.Wk.Yp.3 Oktober 2016). Dijelaskan pula bahwa: “... kuota dan macam peminatan peserta didik perlu dipertimbangakan sarana dan prasarana. Jumlah guru/pendidk dan jumlah jam setiap mata pelajaran ..." (Ww/Wk.Y. 3 Oktober 2016). Hal tersebut secara ekplisit tertuang dalam Kurikulum SMA Negeri 2 Bantul tahun 2016 (Dok/Kurikulum: 63).

Perencanaan program peminatan peserta didik di SMA Negeri 2 Bantul dengan membentuk panitia program penentuan peminatan yang terintegrasi dalam panitia penerimaan peserta didik baru (PPDB). Tugas panitia tersebut adalah menyeleksi dan menentukan program peminatan peserta didik baru sesuai dengan kurikulum 2013. 
Komponen dan kriteria persyaratan, sebagaimana dikemukakan informan dalam wawancara berikut: "Komponen dan kriteria yang menjadi dasar penentuan peserta didik diterima program peminatan MIPA adalah (1) Nilai UN SMP peserta didik, (2) Nilai pengetahuan Matematika dan IPA, (3) peserta didik dari hasil tes SMA, (4) Test IQ peserta didik, (5) Minat peserta didik di program peminatan MIPA, (5) Kuota kelas MIPA SMA Negeri 2 Bantul". (Ww.Wk.Y. 3 Oktober 2016). Sedangkan komponen dan kriteria yang menjadi dasar penentuan peserta didik diterima program peminatan IPS adalah (1) Nilai UN SMP peserta didik, (2) Nilai pengetahuan Matematika dan IPA dari hasil tes SMA, (4) Test IQ peserta didik, (5) Minat peserta didik di program peminatan IPS, (5) Kuota kelas IPSdi SMA Negeri 2 Bantul" (Ww.Wk.Y. 3 Oktober 2016). Hal tersebut sesuai dengan dokumen kurikulum SMA Negeri 2 Bantul tahun 2016 bahwa dasar pengelompokan program peminatan adalah capaian nilai $\mathrm{UN}$, hasil placement tes, hasil penelusuran minat siswa dan rekomendasi psikolog (Dok/kurikulum),

\section{Pengorganisasian (Organizing)}

Pengorganisasian (organizing) program peminatan peserta didik dalam Kurikulum 2013 di SMA 2 Bantul: “... melibatkan kepala sekolah, guru mata pelajaran, guru bimbingan konseling, walikelas, dan orang tua peserta didik untuk bekerja sama sesuai dengan peran nya dan menciptakan lingkungan sekolah yang kondusif agar mencapai hasil yang optimal" (Ww/Ks.Is. 27 September 2016). Senada dengan penuturan Kepala Sekolah, bahwa: "Panitia PPDB mempunyai tugas menyelenggarakan layanan pemilihan dan penetapan peminatan yang sesuai dengan potensi peserta didik dan kesempatan yang ada pada satuan pendidikan ..." (Ww/Wk.Yp. 3 Oktober 2013).

“...guru bimbingan konseling dalam program peminatan peserta didik mempunyai tugas antara lain memberikan layanan konsultasi kepada orang tua atau peserta didik .., menyelenggarakan pendampingan dalam pembelajaran... dengan cara memberikan layanan konseling individual, konseling kelompok, bimbingan kelompok, dan bimbingan klasikal, menyelenggarakan evaluasi dan tindak lanjut yang perlu dilakukan untuk pengembangan potensi peserta didik..., dan bekerjasama dengan guru mata pelajaran dan pendidik lainnya, melakukan pembinaan dan pengembangan serta penyaluran potensi peserta didik secara optimal " (Ww/G5.Bk. Dd. 15. Oktober 2016).

\section{Pelaksanaan program peminatan}

Sekolah menfasilitasi peserta didik yang belum mantap dengan pilihan program peminatan, hal ini dijelaskan informan berikut: "Sekolah memberi kesempatan pada peserta didik untuk pindah program peminatan apabila ingin pindah dengan mempertimbangan kuota yang ada dan peserta didik memenuhi syarat di program yang akan dipilih" (Ww/Wk.Yp. 3 Oktober 2016); (Ww/G5.Bk. Dd . 15 Oktober 2016)

Mayoritas jumlah kelas dan jumlah peserta didik didominasi kelas program peminatan peminatan MIPA. Hasil analisis dokumen data peminatan bahwa sebagian besar peserta didik berdasarkan angket minat siswa memilih program peminatan MIPA dan hanta beberapa anak yang memilih program IPS dan bahasa. Hal ini karena sebagian besar peserta mempunyai nilai ujian nasional rata-rata di atas 85.

SMA Negeri 2 Bantul menyelenggarakan pembelajaran program peminatan peserta didik, dikemukakan informan dalam wawancara berikut: “ ... menyelenggarakan pembelajaran program peminatan pukul 07.00-13.45 WIB kecuali hari Jumat hanya sampai jam 11.15. Waktu belajar 
menggunakan sistem semester dengan jadwal yang telah kami susun pada awal semester. Jadwal disusun berdasarkan Kurikulum 2013" (Ww/WK.Yp, 3 Oktober 2016); (D/ 14/10/2016)(O/23/09/2016)

SMA Negeri 2 Bantul pada tahun ajaran 2016/2017 menyelenggarakan pembelajaran dengan mata pelajaran wajib, mata pelajaran peminatan MIPA dan IPS serta mata pelajaran lintas minat untuk program MIPA adalah geografi dan bahasa Inggris. Sedangkan untuk peminatan IPS mendapat pelajaran lintas minat fisika dan bahasa Inggris. Sedangkan untuk mata pelajaran pendalaman minat tidak diberikan (Ww/Wk.Yp: 3 Oktober 2016), (Ww/G1.Mipa.Sr: 8 Oktober 2016), (Ww/G3.Ips.Sd 8 Oktober 2016), (Ww/S3. Xs.Az: 29.September 2016), (Ww/S1.Xa.Fn: 24 September 2016). Dijelaskan pula, bahwa: “...program pendalaman minat... perlu biaya besar dan perlu bekerjasama dengan perguruan tinggi, dan ini merupakan salah satu kendala dalam menyelenggarakan program peminatan peserta didik dalam kurikulum 2013 " (Ww.Ks.Is. 27 September 2016).

Berdasakan analisis dokumen kurikulum (Dok: kurikulum/21/10/2016) kegiatan ekstrakurikuler di SMA Negeri 2 Bantul terdiri atas ekstrakurikuler wajib dan ekstrakurikuler pilihan. Kegiatan Ekstrakurikuler wajib diikuti oleh kelas X, yaitu: Pramuka dan English Conversation. Sedangkan Kegiatan ekstrakurikuler pilihan sebagai berikut: Keagamaan, Keolahragaan, Kepemimpinan (Paskibraka/Pleton inti), PMR, Seni (Teater, Band, Seni Tari, Paduan Suara), Kelompok Ilmiah Remaja (Smadaba Reseacrh Community), Kelompok Majalah Kreasi, Kewirausahaan, dan Pembinaan Olimpiade Sains dan Teknologi.

\section{Pengawasan}

Kegiatan pengawasan untuk mengontrol pelaksanaan penentuan program peminatan peserta didik dalam Kurikulum 2013 di SMA 2 Bantul dijelaskan informan dalam wawancara 150 berikut : “...Panitia juga membuat Laporan secara tertulis tentang pelaksananan penerimaan siswa baru dan hasil penentuan program peminatan peserta didik baru... bila laporan tidak sesuai dengan prosedur maka perlu direvisi lagi sesuai dengan peraturan yang ada" (Ww/Ks.Is. 27 September 2016). Hal ini sesuai denga hasil wawancara berikut: “...penyusunan dokumen Kurikulum SMA Negeri 2 Bantul, sekolah selalu berkoordinasi dengan pengawas Pembina pendidikan dan Kepala Bidang Pendidkan Menengah Atas .... dan yang merekomendasi pengesahan dokumen oleh Kepala Dinas Pendidikan Menengah dan Non Formal Kabupaten Bantu" (ww/Wk.Y. 3 Oktober 2016).

\section{Faktor Pendukung dan Penghambat Program Peminatan}

Faktor pendukung pelaksanaan program peminatan peserta didik dalam Kurikulim 2013 di SMA Negeri 2 Bantul sebagai berikut : Animo masyarakat untuk menyekolahkan di SMA N 2 Bantul sangat besar .Peserta didik yang masuk di SMA Negeri 2 Bantul nilai UN SMP rata-rata lebih dari 85 , merupakan sekolah sehat, sekolah peduli dan berbudaya lingkungan, sekolah responsif gender, sekolah berintregrasi. Semangat warga sekolah untuk meningkatkan diri, mengangkat prestassi sekolah sangat besar. Sinergi sekolah, dewan sekolah, orang tua, Dikmenof, PTS, LSM dan instansi terkait sangat kuat.

Faktor penghambat program peminatan sebagai berikut: (1) belum ada program pendalalaman minat; (2) hasil ujian nasional belum optimal; (3) hasil SNPTN belum optimal. Untuk mengatasi hambatan program peminatan melalui kegiatan: (1) program peningkatan kualitas lulusan dengan kegiatan pendalaman materi, achievement Motivation Training (AMT), Penelusuran potensi kelanjutan studi, Try out Ujian nasional dan SBMPTN dan program pasca ujian nasional dalam bentuk tatap muka untuk mempersiapkan peserta didik menempuh SBMPTN dan (2) 
melaksanakan program unggulan yaitu: Sekolah Adiwiyata, Sekolah Sehat, Sekolah berbasis riset, Kelas Cerdas Istimewa dan Sekolah Model berbasis Budaya.

\section{Pembahasan}

Program peminatan peserta didk dalam Kurikulum 2013 merupakan proses pengambilan pilihan dan keputusan oleh peserta didik tentang peminatan belajar, yang didasarkan atas pemahaman potensi diri dan peluang yang diselenggarakan pada satuan pendidikan dan proses pembelajaran berbasis minat peserta didik. Program peminatan peserta didik adalah proses yang berkesinambungan untuk memfasilitasi peserta didik mencapai keberhasilan proses dan hasil belajar serta perkembangan optimal dalam rangka mencapai tujuan pendidikan nasional. Akhmad Sudrajat (2013) menyatakan bahwa: "bimbingan dan konseling memiliki peran strategis untuk membantu siswa agar dapat menavigasi perjalanan hidupnya melalui pengambilan keputusan dalam rangka memilih, meraih dan mempertahankan kariernya guna mewujudkan kehidupan yang produktif dan sejahtera, serta untuk menjadi warga masyarakat yang peduli kemaslahatan umum".

Program peminatan peserta didik kurikulum 2013 sangat relevan dengan ajaran Ki Hadjar Dewantara. Sistem pendidikan menurut Ki Hadjar Dewantara dikembangkan berdasarkan lima asas pokok yang disebut Pancadarma Taman Siswa (Soeratman, 1985: 111) bahwa Kodrat Alam. Kemerdekaan, Kebudayaan, Kebangsaan dan Kemanusian. Konsep pendidikan yang beliau usulkan adalah pendidikan yang memerdekaan peserta didik. Peserta didik diberi kemerdekaan untuk memilih dan menentukan program peminatan sesuai dengan mintanya dan bakatnya sehingga dapat berkembang optimal untuk menemukan jati diri sebagai bangsa Indonesia yang bangga dan cinta dengan tanah airnya dan mandiri. Untuk menentukan program peminatan ada seleksi ini menunjukkan bahwa pelaksanaan harus tertib, damai dan tata tentram dan tidak ada paksaan.

Konsep Ki Hajar Dewantoro dikenal dengan "Konsep Trisakti Jiwa" yang terdiri dari cipta, rasa, dan karsa. Untuk melaksanakan segala sesuatu maka harus ada kombinasi yang sinergis antara hasil olah pikir, hasil olah rasa, serta motivasi yang kuat di dalam dirinya. Bila hanya mengandalkan salah satu diantaranya saja maka kemungkinan akan tidak berhasil. Menurutnya Ki Hajar Dewantara sekolah adalah taman bermain dimana seorang anak mendapatkan ilmu baru, pengetahuan baru dengan mengembangkan daya cipta, rasa dan karsa secara menyenangkan dalam lingkungan yang sesuai dengan perkembangan sang anak. Hal ini sesuai dengan proses pembelajaran program peminatan yang menyelenggarakan mata pelajaran wajib Pendidikan Agama, PKn, Bahasa Indonesia, Matematika, Sejarah Indonesia, Bahasa Inggris yang bertujuan untuk mengembangkan kompetensi kognitif (cipta) dan afektif (rasa). Untuk mengembangkan kompetensi afektif (rasa) dan psikomotorik (karsa) ada mata pelajaran seni budaya, prakarya dan kewirausahaan serta pendidikan jasmani, olah raga raga, dan kesehatan. Setiap peserta didik dapat memilih sejumlah mata pelajaran yang bersifat pendalaman atau perluasan peminatan. Peserta didik menempuh kelompok mata pelajaran yang ditetapkan.

Untuk melaksanakan program peminatan dipelukan pengelolaan atau manajemen yang meliputi perencanaan, pengorganisasian, penggerakkan dan pengawasan, sebagai berikut:

\section{Perencanaan program peminatan peserta didik}

Perencanaan program peminatan peserta didik dilakukan dengan menyusun berbagai program dan kegiatan sekolah. Dimulai dengan adanya kebijakan sekolah membentuk panitia PPDB yang bertugas menentukan peserta didik baru dan peserta didik dalam program peminatan sesuai dengan 
kurikulum 2013; menetapkan macam dan kuota yang mempertimbangkan jumlah guru dengan mata pelajaran yang diampunya, jumlah jam setiap mata pelajaran yang sesuai dengan struktur kurikulum 2013, serta sarana dan prasarana yang ada di sekolah.
Perencanaan program peminatan peserta didik dalam Kurikulum 2013, melalui kegiatan yang digambarkan sebagai berikut:

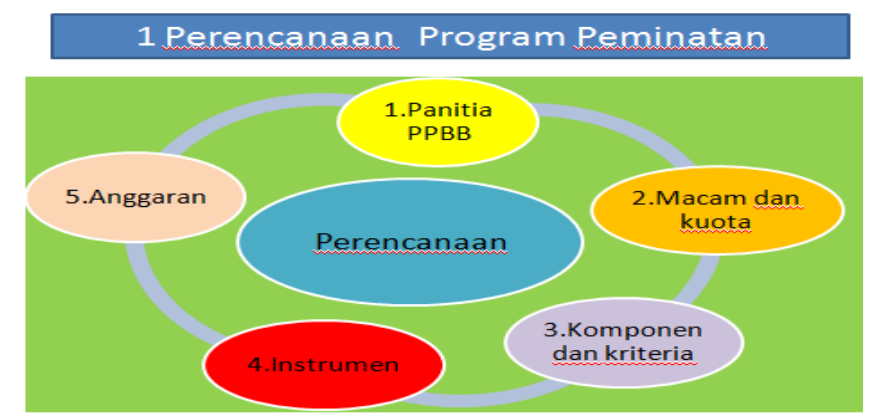

Gambar 1 Perencaan Program Peminatan

2. Pengorganisasian Program Peminatan Peserta Didik

Program peminatan memerlukan mekanisme kerja yang baik yang melibatkan kepala sekolah, guru binbingan konseling, guru mata pelajaran, wali kelas,peserta didik dan orang tua peserta didik untuk bekerja sama sesuai perannya sehingga tercipta lingkungan sekolah yang kondusif agar mencapai hasil yang optimal. Kegiatan organizing dalam manajemen program peminatan sebagai berikut:

a. Menentukan mekanisme program peminatan peserta didik

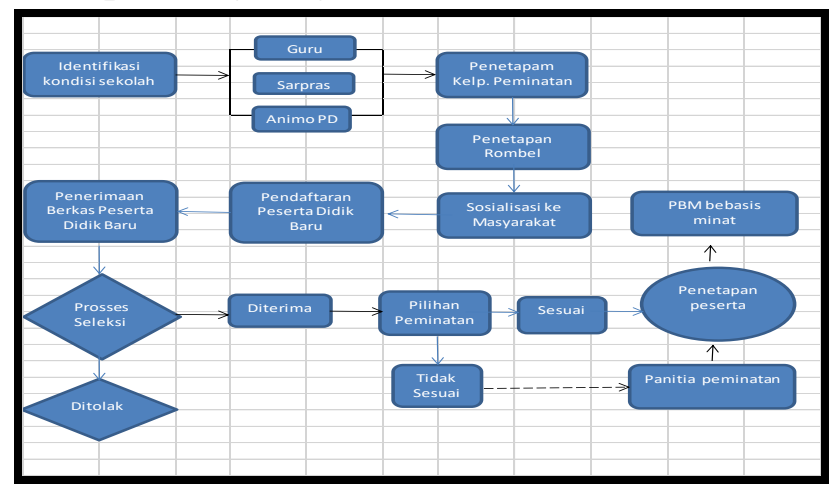

Gambar 2 .Mekanisme Program Peminatan Kurikulum 2013

b. Pembagian tugas yang terlibat dalam program peminatan

Pengorganisasian program peminatan peserta didik melibatkan peran serta dari kepala sekolah, wakil kepala sekolah, guru mata pelajaran, wali kelas ,guru bimbungan konseling, peserta didik dan orang tua peserta didik agar terlaksana dengan baik.

Dalam pengorganisasian program peminatan peserta didik, wali kelas berperan melaksanakan pendampingan dan memberikan pelayanan kepada peserta didik berkenaan dengan informasi sekolah yang sedang dijalani. Orang tua berperan mencermati informasi yang disampaikan oleh sekolah, mendampingi putraputrinya saat proses pendaftaran, pengisian format peminatan peserta didik, memberi motivasi belajar yang kuat atas dasar pilihan peminatan putra-putrinya, Proaktif melakukan konsultasi kepada Guru BK/Konselor dalam 
rangka pendampingan putra-putrinya untuk keberhasilan belajarnya, mendampingi aktivitas belajar putra-putrinya selama di luar sekolah.

\section{Pelaksanaan Program Peminatan Peserta} Didik

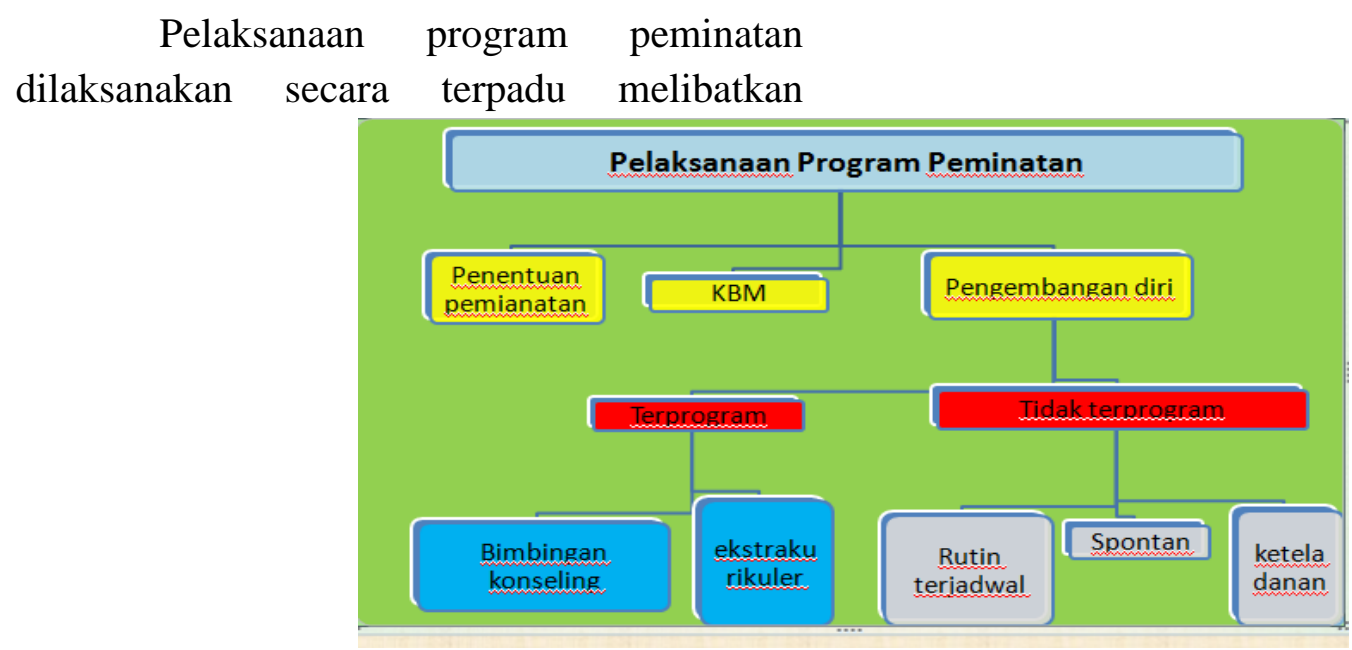

Gambar 3.Pelaksanaan Program Peminatan berbagai pihak agar pelaksanaan kegiatan lebih optimal oleh kepala sekolah bersama-sama staf dan petugas yang terlibat secara integratif dan terencana melakukan tahapan yang direncanakan.
Pelaksanaan program peminatan peserta didik dalam Kurikulum 2013 di SMA Negeri 2 Bantul secara inici melalui kegiatan:

\section{a. Penentuan program peminatan}

Penentuan program peminatan melalui:

(1) Sosialisasi program peminatan dilakukan pada saat pendaftaran peserta didik baru dan saat mendapat angket program peminatan. Pengisian dapat dengan persetujuan Orang Tua. Bila ada kesulitan ada layaman konsultasi dari panitia program peminatan yang terintegrasi pada panitia PPDB; (2) Peserta didik baru mengembalikan angket peminatan belajar yang telah diisi lengkap kepada Panitia Program Peminatan; (3) Panitia PPDB melakukan hasil Test akademik dari sekolah, test Psikologi bekerjasama dengan lembaga psikologi; (4) Panitia program peminatan melakukan analisis dan seleksi dengan dasar nilai ujian nasional SMP, hasil test akademik, test psikologi dan angket minat siswa;(5) Rapat penentuan program pemintan yang dipimpin oleh Kepala Sekolah; (6) Hasil penetapan peminatan peserta didik diumumkan secara tertulis dan terbuka dan peserta didik dikelompokkan berdasarkan peminatan belajarnya: (7) Bagi peserta didik dan orang tua yang kurang sesuai dengan hasil penetapan program peminatan dilakukan konsultasi pada pihak sekolah.

\section{b. Pelaksanaan pembelajaran}

Proses pembelajaran guru mempersiapkan perangkat pembelajaran sebagai berikut: silabus, kriteria ketuntasaan minimal (KKM), program tahunan, program semester, rencana pelaksanaan pembelajaran (RPP), laporan pelaksanaan pembelajaran harian, buku presensi siswa, buku kemajuan kelas, buku nilai ulangan harian, analisis ketuntasan ulangan harian, bukti pembelajaran remidi dan pengayaan.

\section{c. Pelaksanaan pengembangan diri}

Kegiatan pengembangan diri bertujuan memberi kesempatan kepada peserta didik untuk mengembangan dan mengekspresikan diri sesuai dengan kebutuhan, bakat, minat sesuai dengan kondisi Sekolah. Pelaksanakan kegiatan pengembangan diri dilakukan secara terprogram dan tidak terprogram. Strategi pelaksanaan pengembangan diri secara terprogram melalui kegiatan bimbingan konseling secara intrakurikuler untuk kelas X, 
XI, XII dan ekstrakurikuler dilaksanakan setelah kegiatan belajar mengajar. Kegiatan pengembangan diri tidak terprogram merupakan kegiatan yang tidak tercamtum dalam struktur kurikulum 2013. Kegiatan bersifat rutin terjadwal, Spontan/tidak terjadwal dan keteladanan.

\section{Pengawasan (controlling)}

Kegiatan pengawasan dalam menentukan program peminatan peserta didik dilakukan terintegrasi pada panitia penerimaan pesert didik baru dengan mengumpulkan laporan kegiatan. Pengawasan pada proses pembelajaran dan pengembangan diri dilakukan oleh kepala sekolah dan Pengawas
Pembina melalui verifikasi jumlah jam pengajar yang dilaksanakan minimal 2 kali untuk setiap guru. Pengawas juga meneliti kelengkapan dokumen guru mata pelajaran sebagai berikut: program tahunan, program semester, rencana pelaksanaan pembelajaran (RPP), Laporan Pelaksanaan Harian/Agenda mengajar. Buku Presensi Siswa, Buku Kemajuan Kelas, Buku Nilai Ulangan Harian, Analisis Ketuntasan Ulangan Harian, Bukti Pembelajaran Remidi dan pengayaan.Kegiatan pengawasan secara singkat dapat dilihat dalam gambar 4 berikut:

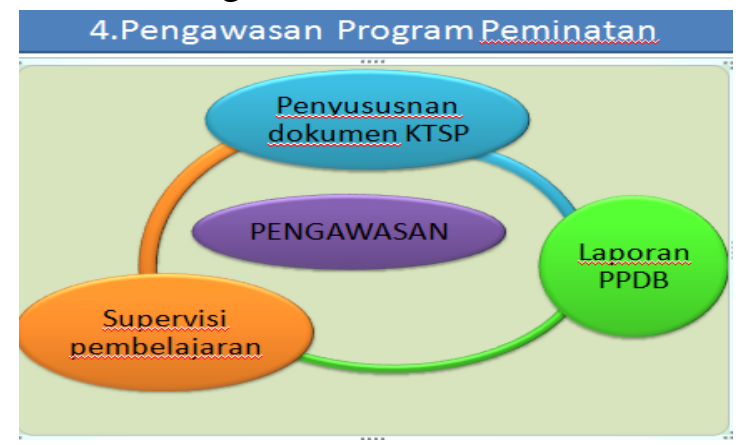

Gambar 4. Pengawasan program peminatan kurikulum 2013

Program peminatan peserta didik kurikulum 2013 sangat relevan dengan ajaran Ki Hadjar Dewantara. Sistem pendidikan menurut Ki Hadjar Dewantara dikembangkan berdasarkan lima asas pokok yang disebut Pancadarma Taman Siswa (Soeratman, 1985: 111) yaitu: Kodrat Alam. Kemerdekaan, Kebudayaan, Kebangsaan dan Kemanusian. Konsep pendidikan yang beliau usulkan adalah pendidikan yang memerdekaan peserta didik. Peserta didik diberi kemerdekaan untuk memilih dan menentukan program peminatan sesuai dengan mintanya dan bakatnya sehingga dapat berkembang optimal untuk menemukan jati diri sebagai bangsa Indonesia yang bangga dan cinta dengan tanah airnya dan mandiri. Untuk menentukan program peminatan ada seleksi ini menunjukkan bahwa pelaksanaan harus tertib, damai dan tata tentram dan tidak ada paksaan.

Konsep Ki Hajar Dewantoro dikenal dengan "Konsep Trisakti Jiwa" yang terdiri dari cipta, rasa, dan karsa. Untuk melaksanakan segala sesuatu maka harus ada kombinasi yang sinergis antara hasil olah pikir, hasil olah rasa, serta motivasi yang kuat di dalam dirinya. Bila hanya mengandalkan salah satu diantaranya saja maka kemungkinan akan tidak berhasil. Menurutnya Ki Hajar Dewantara sekolah adalah taman bermain dimana seorang anak mendapatkan ilmu baru, pengetahuan baru dengan mengembangkan daya cipta, rasa dan karsa secara menyenangkan dalam lingkungan yang sesuai dengan perkembangan sang anak. Secara ringkas relevasi dapat dilihat dalam gambar 5 sebagai berikut: 


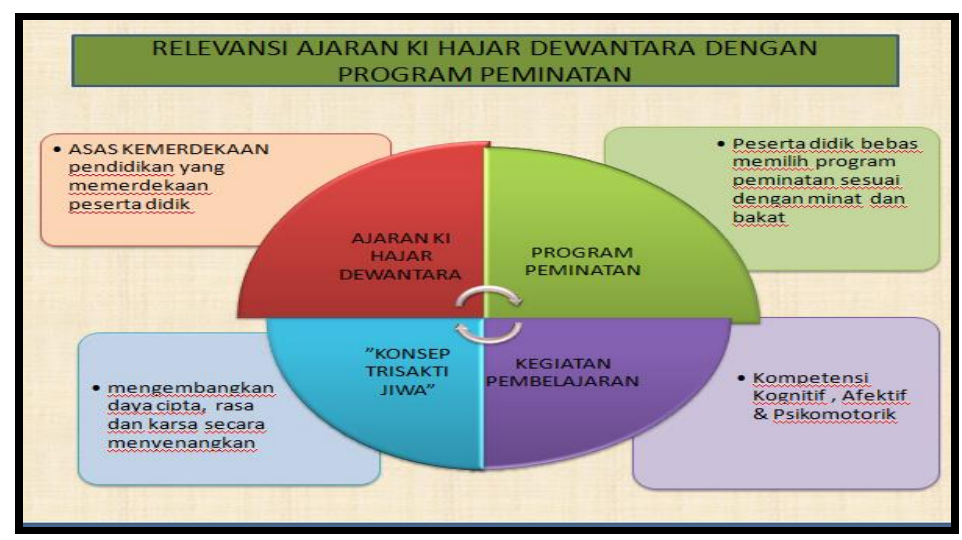

Gambar 5 .Relevansi program peminatan dengan ajaran Ki Hajar Dewantara

\section{SIMPULAN}

Berdasarkan hasil penelitian dan pembahasan manajemen program peminatan peserta didik dalam Kurikulum 2013 tahun pelajaran 2016/2017 di SMA Negeri 2 Bantul dapat disimpulkan sebagai berikut:

a. Perencanaan program peminatan peserta didik melalui kegiatan: membentuk panitia PPDB, menentukan macam dan kuota program peminatan, menentukan komponen dan kriteria, menyiapkan instrumen dan menyusun anggaran.

b. Pengorganisasian program peminatan peserta didik melalui kegiatan: menentukan mekanisme kerja, pembagian tugas semua yang terlibat dalam program peminatan dan menciptakan lingkungan kondusif.

c. Pelaksanaan Program Peminatan peserta didik melalui kegiatan: penentuan peminatan, kegiatan pembelajaran dan pengembangan diri.

d. Pengawasan program peminatan peserta didik melalui kegiatan: penyususnan dokumen KTSP, membuat laporan PPDB dan Supervisi pembelajaran oleh pengawas.

\section{Saran}

Berdasarkan hasil penelitian dan pembahasan dapat dituliskan beberapa saran berikut :
1. Sekolah mengadakan kerja sama dengan perguruan tinggi dan berkoordinasi dengan Dinas Pendidikan dan Dewan Sekolah.

2. Keterlibatan guru bimbingan konseling pada pengorganisasian penentuan program peminatan perlu ditingkatkan.

3. Kegiatan Pengawas Sekolah di sekolah perlu dipertahankan untuk meningkatkan kinerja guru.

4. Orang tua aktif dan responsive mengikuti kegiatan sosialisasi dan pengisian instrument peminatan.

\section{DAFTAR PUSTAKA}

Ahmad Sudrajad. Peminatan siswa dalam kurikulum 2013. Diakses dari https://akhmadsudrajat.wordpress.com/ 2013/02/17/peminatan-siswa-dalamkurikulum-2013/. pada pukul 13.15 WIB, 01 Maret 2016

Friska, Y. D, \& Wiryo, N.(2014 ) Survei Tentang Hambatan-hambatan Selama Proses Peminatan (dalam konteks BK) Berdasarkan Kurikulum 2013 Bagi Siswa di SMA Negeri Se-Kota Surabaya. Jurnal BK UNESA. Volume 04 Nomor 03 Tahun 2014, 1 - 10

Rini Suwandi R, Elizabeth Cristiana. (2013). Implementasi Kurikulum 2013 Bimbingan Dan Konseling Dalam Pelaksanaan Layanan Peminatan Peserta Didik SMA Negeri 2 Lamongan Tahun Ajaran 2013/2014. Jurnal BK 
UNESA. Volume 04 Nomor 03 Tahun $2013,1-9$

Sugiyono. (2013). Metode Penelitian Pendidikan: Pendekatan Kuantitatif, Kualitatif dan $R$ \& $D$. Bandung: Alfabeta. (2015). Metode Penelitian Manajemen: Pendekatan Kuantitatif, Kualitatif, Kombinasi (Mixed Methods), Penelitian Tindakan Kelas (Action
Research ) dan Penelitian Evaluasi. Bandung: Alfabeta.

Soeratman Parsiti.(1985). Ki Hajar Dewantara: Departemen Pendidikan dan Kebudayaan . Proyek Pembinaan Pendidikan Dasar.

Tim. (2013). Praktek Pelayanan Peminatan Peserta Didik. Bogor: PPPPTK Penjas dan BK. 